\title{
A new species and new status in Australian Ranunculus: $R$. diminutus and $R$. acrophilus (Ranunculaceae)
}

\author{
Barbara G. Briggs
}

\begin{abstract}
Briggs, Barbara G. (National Herbarium of New South Wales, Royal Botanic Gardens, Sydney, Australia 2000) 1994. A new species and new status in Australian Ranunculus: R. diminutus and R. acrophilus (Ranunculaceae). Telopea 5:(4): 583-587. Ranunculus diminutus B.G. Briggs, a small stoloniferous species of moist habitats in southern New South Wales and Victoria, is described. A new status and name, $\mathbf{R}$. acrophilus, are provided for a taxon of alpine habitats in the Kosciusko region of southern New South Wales, formerly known as R. muelleri Benth. var. brevicaulis B.G. Briggs.
\end{abstract}

This paper is a precursor to the treatment in the Flora of Australia of Ranunculaceae by the late Hansjörg Eichler, who has contributed so greatly to knowledge of Australia's flora and of Ranunculus in particular.

\section{Ranunculus diminutus B.G. Briggs, sp. nov.}

R. papulento similis sed omnibus partibus minoribus tenuioribusque; lamina foliorum 3.5-16(-22) $\mathrm{mm}$ longa segmentis tribus primariis integris vel aliquando 2-3-lobatis dentatisve; petalis 3.5-6.2 mm longis $0.6-2.0 \mathrm{~mm}$ latis; acheniis 6-28; differt.

TYPe: NeW SOUTH WALES: Southern Tablelands: $4 \mathrm{~km}$ E of Tarago, Tarago-Nerriga road, at creek crossing, $\mathrm{S}$ end of Lake Bathurst $35^{\circ} 05^{\prime} \mathrm{S} 149^{\circ} 42^{\prime} \mathrm{E}$, B.G. Briggs 7951 , 15 Feb 1985; holo NSW, iso CANB, CHR, MEL, K, MO, B.

Small stoloniferous herb, pilose or sparsely pilose with long soft hairs, forming a low open turf or taller-growing if among other vegetation. Stolons with internodes to $8 \mathrm{~cm}$ long. Leaves: petioles $5-50(-120) \mathrm{mm}$ long; lamina of narrow or very narrow lanceolate segments with a gland at each apex, the 3 primary segments entire and $0.8-3(-4)$ $\mathrm{mm}$ broad, or less frequently with $2-3$ lobes or teeth, the median segment $3.5-16(-22)$ $\mathrm{mm}$ long, the laterals $2-13 \mathrm{~mm}$ long. Flowering stems $1-8 \mathrm{~cm}$ tall, with $1-4$ flowers and 1-2 linear bracts $2.5-11 \mathrm{~mm}$ long. Receptacle sparsely pilose. Sepals $5-6$, somewhat reflexed in older flowers, elliptic, 3-3.5 mm long, c. $2 \mathrm{~mm}$ broad, sparsely pilose or glabrous. Petals 5-8, narrow-elliptic or narrow-oblong, 3.5-6.2 mm long, 0.6-2.0 mm broad, glossy, golden yellow or rarely fading to white; nectary $1 / 4-1 / 3$ of petallength from base, the lobe semicircular or ovate, the margin usually irregular or erose and \pm truncate. Stamens 15-25. Achenes 6-28, 1.0-1.8 mm long, the lateral faces smooth or finely wrinkled or obscurely ridged, the dorsal ridge usually not thickened; beak slender, sharply bent antrorsely. Flowering mostly September to February. Chromosome number $2 n=48$. Fig. 1 .

DistriBUTION: Southern Tablelands of New South Wales south from near Lake George, in tableland and montane tracts mostly below $1000 \mathrm{~m}$ altitude, and in both east and west Victoria (East Gippsland and the Volcanic Plains). On moist or intermittently moist mud, peat or rarely sand, often on the margins of lakes or pools. 

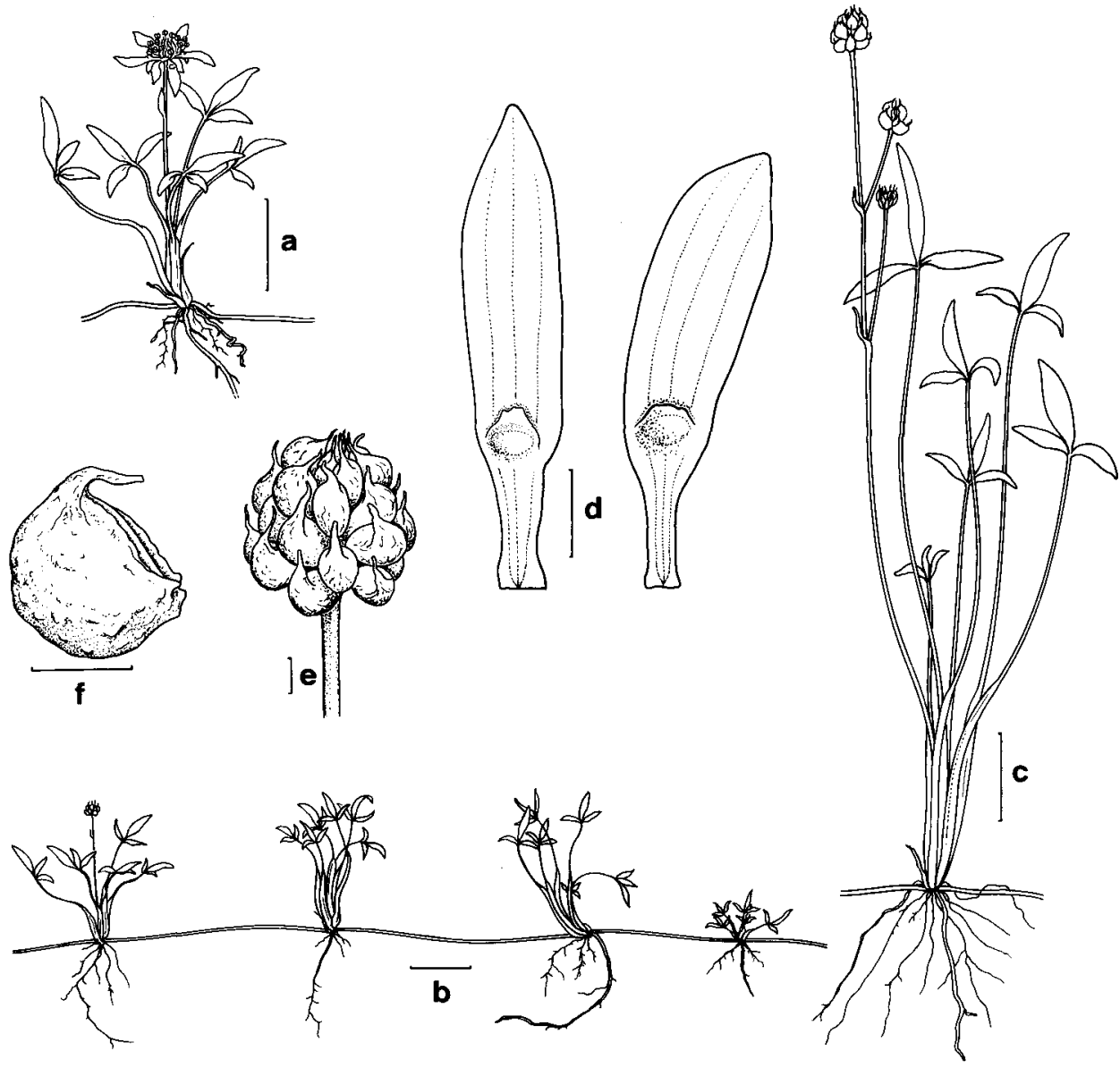

Figure 1. Ranunculus diminutus. a-c, habit showing variation in size; $d$, petals with nectaries (adaxial view); $\mathbf{e}$, head of achenes; f, single achene; a-d from holotype; e-f from Eichler 13310. Scale bars: $\mathrm{a}-\mathrm{c}=1 \mathrm{~cm}, \mathrm{~d}-\mathrm{f}=1 \mathrm{~mm}$.

At several sites where it occurs adjacent to R. papulentus Melville, the latter grows in shallow water or very close to the water's edge, whereas $R$. diminutus forms a zone between the $R$. papulentus and the surrounding grassland.

The epithet is from the Latin diminutus, made small, diminished, alluding to its small size in comparison with the allied species $R$. papulentus.

CONSERVATION Status: Not considered at risk, but its abundance should be monitored since most occurrences are in regions of grassland subject to grazing.

This taxon was referred to as Ranunculus 'species B' in the Flora of New South Wales (Briggs \& Makinson 1990: 165).

Chromosome counts (mitotic counts, not previously reported) by Briggs and by Menadue (pers. comm.) show $2 n=48$ in $R$. diminutus but $2 n=96$ in R. papulentus. Relevant vouchers are as follows: 


\section{$R$. diminutus $2 n=48$}

Lake Bathurst, Johnson, Mar 1964 (NSW 69611);

Pipers Creek, Kosciusko area, E. Briggs, Feb 1964 (NSW 69625);

Lake Omeo, Benambra, B. Briggs, 26 Dec 1964, (NSW 72451);

Lake George, $35^{\circ} 0-^{\prime} \mathrm{S} 149^{\circ} 2^{\prime}$ E, Menadue \& Crowden E22, 26 Jan 1984

(HO, NSW).

\section{$R$. papulentus $2 n=96$}

Thredbo River near Jindabyne, G. Briggs, Jan 1960 (NSW 49092);

Lake George $35^{\circ} 0-^{\prime} \mathrm{S} 149^{\circ}$ 2-'E, Menadue \& Crowden E28, 26 Jan 1984 (HO, NSW).

$R$. diminutus shows considerable resemblance to $R$. papulentus in the general form of leaves, flowers and achenes. Apart from the chromosome number, the larger petals (7-12 $\mathrm{mm}$ long, 2-4 mm broad) of $R$. papulentus appear to be the most reliable distinction from $R$. diminutus (petals $3.5-6.2 \times 0.6-2.0 \mathrm{~mm}$ ). $R$. papulentus also differs in its larger size, with flowering stems $3-30 \mathrm{~cm}$ tall, leaves with the 3 primary segments each with 3-5 lobes or teeth or less often entire, median primary leaf segment 20-40 mm long, achenes mostly 12-36, 1.7-3.6 mm long with the lateral faces irregularly wrinkled or pitted or rarely smooth, when mature often with the dorsal ridge pale and thickened. Both species show considerable variation in size, especially in the length of flowering stems and petioles and also the size of leaves; this variation is associated with localised environmental conditions and is similar to that reported in $R$. nanus Hook. and other species by Menadue and Crowden (1989, 1990). Small plants of $R$. papulentus are therefore sometimes difficult to distinguish from $R$. diminutus; in view of the difference in chromosome numbers, such plants are not likely to be hybrids. The range of $R$. papulentus is from a few scattered locations in the Central Tablelands of New South Wales (Blayney, Mt Wigadon N of Bathurst and Wingecarribee Swamp), through the N.S.W. Southern Tablelands, with one record from the south of the South Western Plains, to Victoria and the Murray and South-eastern regions of South Australia.

Other species somewhat resembling $R$. diminutus are the maritime $R$. acaulis Banks \& Sol. ex DC. (Tasmania, New Zealand, Chile) with much broader fleshy leaflets, and the rare $R$. collicola Menadue (published as collicolus, orthography changed for the reasons given by Nicolson 1987). The latter differs in its even smaller size, dull petals, fewer achenes and short recurved styles. Small plants of $R$. collinus $\mathrm{R}$. Br. ex DC. are separable since that species has broader leaves with more lobes and achenes with 2-5 prominent broad oblique or nearly longitudinal ridges on each face.

Selected SPEcimens EXAMINed: New SOUth Wales: Southern Tablelands: SW of Collector, $34^{\circ} 57^{\prime} \mathrm{S}$ $149^{\circ} 25^{\prime}$ E, Eichler 13310, 22 Nov 1956 (AD, CANB); Lake Bathurst, Burbidge 5637, 16 Jun 1958 (CANB, NSW); Lake George, Gray 3512, 4 Mar 1956 (CANB, NSW), Canning 4086, 7 Oct 1976 (CBG, NSW), Martin NSW 63756, 14 Oct 1962 (NSW); Cooleman Plain, 27 km NNE of Kiandra, Rodd \& Coveny 2685, 13 Dec 1969 (NSW); Muddah Lake, M. Mueller 2262, 1954 (NSW, GH); Fat Hen Lake, Coolringdon, Walker ANU 164, Jan 1962 (CANB, NSW); Black Lake near Bungarby, c. 40 miles [65 km] S of Cooma, Costin, 8 Nov 1961 (CANB, NSW). Victoria: East Gippsland: Lake Omeo, Benambra, Ford NSW 49777, Jan 1957 (NSW), Wakefield, Nov 1962 (MEL 1510968), Aston 1297, Nov 1964 (MEL). Volcanic Plains: Skipton, Whan (MEL, NSW); Lake Kennedy Wildlife Reserve, $15 \mathrm{~km}$ ESE of Hamilton, Beauglehole 63024, 10 Jan 1979 (MEL); Lake Corangamite, $11.5 \mathrm{~km}$ SW of Cressy, Beauglehole 56801, 3 Nov 1977 (MEL).

\section{Ranunculus acrophilus B.G. Briggs, nom. \& stat. nov.}

REPLACED NAME: $R$. muelleri var. brevicaulis B.G. Briggs (1960a [1959]: 316); the existence of $R$. brevicaulis Hook. (Hooker 1829: 13) precludes the use of brevicaulis as the specific 
epithet. The epithet is from the Greek akron, a height or summit, and phileo to love, referring to its occurrence only on the highest ridges of Australia's highest mountain area, the Kosciusko plateau.

When this taxon was first described, it was placed in varietal rank under $R$. muelleri on the ground that the 'morphological differences between the varieties are small and are largely quantitative in nature'. Natural hybrids occur among the group of eleven species of Ranunculus, including $R$. muelleri and $R$. acrophilus, of the Tablelands in southern New South Wales and eastern Victoria (Briggs 1962). In reporting studies of these hybridisations, when these two species were still placed in varietal rank, I commented (op. cit. p. 376) that "The nature of the barriers to gene flow maintaining the distinctness of these varieties in contiguous areas presents a problem similar to that of the maintenance of the various interfertile species'. A later comment (Briggs 1986) was that 'The varieties are interfertile but the ecotone [between grassland with var. muelleri and feldmark with var. brevicaulis] is so sharp that there is scarcely any zone for plants adapted to intermediate conditions'. The most prominent features of $R$. acrophilus, its compact growth with short scapes and its long coarse hairs, would appear to be clearly adaptive to its windswept habitat, where there is not sufficient vegetation to hold a cover of snow during the winter.

These taxa are morphologically and genetically distinct and occupy different habitats. They maintain their distinctness although the very narrow belt of feldmark habitat on the Kosciusko plateau is surrounded by alpine grassland, the habitat of $R$. muelleri.

Biologically $R$. acrophilus resembles other interfertile Ranunculus entities in the mountain regions of south eastern Australia that have been treated (Briggs 1960a, 1962, 1986) as species. Like them, its distinctiveness is largely maintained by ecological differentiation that restricts hybrids to narrow ecotones. In addition, there is some seasonal isolation with a difference of two to three weeks between the peak flowering of this and $R$. muelleri, although there is considerable overlap of flowering time (Briggs $1960 \mathrm{~b})$. The category of variety has been used so indiscriminately in the past that it is best avoided. Despite the restricted range of $R$. acrophilus, there is no sound reason to accord this taxon a lesser status than that of allied species. I therefore take this opportunity to raise this former variety to the more appropriate rank of species.

The differences between, and distributions of, R. acrophilus and R. muelleri were summarised by Briggs \& Makinson (1990, while still retaining varietal status for these taxa) and are as follows:

$R$. acrophilus: Leaves: petiole $0.5-2.5 \mathrm{~cm}$ long, shorter than lamina; lamina elliptic to obovate, mostly with 2 long teeth, upper surface and margins with rigid spreading hairs 3-4 mm long. Flowering stems $2-4 \mathrm{~cm}$ long, usually shorter than the leaves. Achene beak $1.2-2.2 \mathrm{~mm}$ long.

Distribution: New South Wales: Southern Tablelands: Kosciusko Plateau. In open feldmark communities on the highest windswept alpine ridges from the Etheridge Range to Mt Twynam, above $2040 \mathrm{~m}$ altitude.

R. muelleri: Leaves: petiole 1-9 cm long, longer than lamina; lamina elliptic, entire or with 2 short teeth, upper surface with appressed or suberect hairs 2-3 mm long, margins with appressed hairs. Flowering stems $2-16 \mathrm{~cm}$ long, usually overtopping the leaves. Achene beak 1-1.5 mm long.

Distribution: New South Wales: Southern Tablelands: Kosciusko Plateau. Victoria: Eastern Highlands: Bogong High Plains. In alpine and subalpine grassland and herbfield; in moist sites on valley floors between 1675 and $1830 \mathrm{~m}$ altitude but widespread in grassland and herbfield above $1830 \mathrm{~m}$ altitude. 
CONSERVATION STATUS: $R$. acrophilus: $2 \mathrm{RC}$, occurring in a very restricted area within Kosciusko National Park. Trends to warmer temperatures would, however, threaten its survival. $R$. muelleri: Not considered to be at risk.

\section{Acknowledgements}

I wish to express my appreciation of the great help given to me by the late Dr Hansjörg Eichler in studies of Ranunculus. We discussed the treatment of R. diminutus, but his kind encouragement started with my first botanical project - the early studies of Ranunculus cited above - and far exceeded what has been involved in this paper. Dr Yvonne Menadue and Dr Ron Crowden provided unpublished chromosomal and morphological information. Expert assistance from Robert Makinson (now of CBG, formerly at NSW) and Barbara Wiecek, discussions with Dr L.A.S. Johnson and illustrations by David Mackay are also gratefully acknowledged. Opportunity to examine and/or borrow specimens in AD, CANB, CBG, GH, K, MEL, MO, and US was of assistance to the study. The work was aided by a grant from the National Herbarium and Royal Botanic Gardens Scientific Research Fund.

\section{References}

Briggs, B.G. (1960a [1959] Ranunculus lappaceus and allied species of the Australian mainland I. Taxonomy. Proc. Linn. Soc. New S. Wales 84: 295-324.

Briggs, B.G. (1960b) Studies in the experimental taxonomy of Ranunculus and Darwinia. Ph.D. Thesis, University of Sydney (unpublished).

Briggs, B.G. (1962) Interspecific hybridization in the Ranunculus lappaceus group. Evolution 16: 372-390.

Briggs, B.G. (1986) Alpine ranunculi of the Kosciusko plateau - habitat change and hybridization. In B.A. Barlow (ed.), Origin and evolution of Australasian alpine biota. (CSIRO: Melbourne). Pp. 401-412.

Briggs, B.G. \& Makinson, R.O. (1990) Ranunculaceae. Pp. 155-167 in G. Harden, (ed.) Flora of New South Wales, vol.1 (New South Wales University Press: Sydney).

Hooker, W.J. (1829) Flora Boreali-Americana. Vol. 1, part 1.

Menadue, Y. \& Crowden, R.K. (1989) The Tasmanian species of Ranunculus - a new key. Pap. E Proc. Roy. Soc. Tasmania 123: 87-96.

Menadue, Y. \& Crowden, R.K. (1990) Leaf polymorphism in Ranunculus nanus Hook. (Ranunculaceae). New Phytol. 114: 265-274.

Nicolson, D.H. (1987) Species epithets ending in-cola, a retraction concerning-colus,-colum. Taxon 36: 742-744. 